\title{
THE INTEGRATED PEATLAND MANAGEMENT SYSTEM (IPMS)
}

\author{
${ }^{1}$ Khalimatus Sa'diyah, ${ }^{2}$ Angga Puja Asiandu, ${ }^{3}$ Widya Sari \\ ${ }^{1}$ Department of Politics and Governance, University of Gadjah Mada, Yogyakarta, Indonesia \\ ${ }^{2}$ Department of Biology, University of Gadjah Mada, Yogyakarta, Indonesia \\ ${ }^{3}$ Department of Physics, University of Gadjah Mada, Yogyakarta, Indonesia \\ ${ }^{1}$ khalimatussadiyah808@mail.ugm.ac.id, ${ }^{2}$ angga.puja.asiandu@mail.ugm.ac.id, \\ ${ }^{3}$ widya4895sari@mail.ugm.ac.id
}

\begin{abstract}
Peatland is a rich ecosystem containing many organic components. This ecosystem is composed of plant residue materials that have not undergone a complete decomposition process due to the high water content of the land. Peatland is a rich biodiversity-ecosystem, including plants, animals, and microorganisms. The biological resources contained in the peatland are the assets supporting the survival of the community. However, various kinds of damage both caused by humans and caused by nature seriously threaten this ecosystem's sustainability. This study aimed to formulate the ideas regarding sustainable peatland use as a support for community life. This study is descriptive qualitative research. While the method used in this study is the literature study, and the data used in this study are secondary data obtained from various sources. Based on the analysis of the collected data, the authors put forward the idea of sustainable peatland use under the name of The Integrated Peatland Management System (IPMS). IPMS is an integrated peatland management system that still pays attention to the conservation aspects by dividing the peatland into three zoning systems. Zone I is an eco-tourism zone, Zone II is a utilization zone, and Zone III is a conservation zone for the peatland ecosystem. The sustainable use of peatlands can be implemented through IPMS to support community life today and in the future.
\end{abstract}

Keywords: Conservation, Eco-tourisms, Peatland, Sustainability, Zoning

DOI: $10.33541 /$ sp.v21i3.2180

Sociae Polites : Majalah IImiah Sosial Politik

Faculty of Social and Political Science, Universitas Kristen Indonesia

ISSN 1410-3745 print/ ISSN 2620-4975 online

Volume 21, Number 2 (Youth Peatland Conference)

Pages 159-170 


\section{Introduction}

\subsection{Background}

The total area of peatland in the world is approximately 420 million hectares (Clymo, 1987; Ritung \& Sukarman, 2016. In Indonesia, the distribution of peatland reaches around 14.9 million hectares only in Kalimantan, Sumatera, and Papua (Ritung \& Sukarman, 2016). Among ASEAN countries, Indonesia is the most extensive peatlands. Some people have not been able to use the land to cultivate plants that have the potential to be used as food security. The agricultural sector plays a vital role in human survival. The potency of peatlands used as crop cultivation can be a solution when the problem of conversion of agricultural land is increasingly common. The island of Java, which supplies the largest amount of food for Indonesia, at 60\%, is currently experiencing land reduction (Masganti et al., 2014).

Indonesian people are highly dependent on rice as the primary food source. While on the other hand, the demand for this commodity is increasing every year. It is not surprising if this fact makes the Indonesian government import it from other countries to meet the demand. If these conditions continue in the future, it will result in unsustainable food security for Indonesia. Indonesia has a large number of plants that have the potential to be used as food sources that are grown in peatlands. One of them is the breadfruit Tree or Artocarpus altilis. This plant could be cultivated in the peatland.

Peatlands can also be useful in other sectors, for instance, used as eco-tourism that supports the economic and social sectors in the surrounding community. According to the Central Statistics Agency of Indonesia, the number of poverty in Indonesia until March 2020 is 26.42 million people. The poverty of Indonesia is increased compared to 2019. In 2019, within the same month, there were only 25.14 million people in poverty. This problem cannot be overcome by relying only on the government alone. Therefore, it takes the role of the community and cooperation with several parties to gradually reduce the poverty level.

From the ecological perspective, the concept of eco-tourism on peatlands will help the community awarned about the importance of protecting the environment, including peatlands. Furthermore, from the social side, these concepts will be able to improve the cooperative relationship between the community and local government in developing an area, especially the peatland. Eco-tourism that will be developed is community-based, so the active role of the local community in its management is needed. However, it does not mean that the community itself manages the business. Directly, there will be many workers working in these places thus reduces the number of unemployed in the area around peatlands. Considering that in Indonesia, the number of open unemployment is still high, $4.99 \%$ in particular, based on data from the Central Statistics Agency.

The concept of eco-tourism and the development of breadfruit plants on peatlands are part of land conservation, where the implementation of these ideas will optimize the sustainable utilization of peatland resources. This concept is also directly in line with some of the goals of the Sustainable Development Goals (SDGs). Among the ideas are reducing poverty, achieving food security, and supporting sustainable agriculture, supporting inclusive and sustainable economic growth for the community.

\subsection{Research Questions}

Based on the background described above, several problems can be found related to the sustainable utilization of peatlands, including What is The Integrated Peatland Management System (IPMS)? What is the potency of breadfruit cultivation on peatlands as an 
alternative food source for the community? What are the strategies to develop eco-tourism in peatlands? And What are the conservation strategies of peatlands?

\subsection{Purpose and Objective}

Based on the research questions above, the purpose and objective of this research are to explain The Integrated Peatland Management System (IPMS), to determine the potency of breadfruit cultivation on peatlands as an alternative food source for the community, to determine the strategies for developing eco-tourism on peatlands to improve the economy of the surrounding community and to determine the peatland conservation strategies.

\section{Literature Review}

\subsection{Peatland}

Peatland is one of the natural resources that potentially used in the welfare of human life (Sudrajat \& Subekti, 2019). This ecosystem is formed due to the addition and accumulation of fresh organic materials faster than the degradation process. The main compositions of peatlands are organic matters that decomposed incompletely with carbon contents more than 50\%. Peatland formation takes a long period. The formation of $1 \mathrm{~cm}$ peat needs up to 10 years long.

One of the differences between peatlands and other ecosystems is the decomposition process and time of plant residues. In peatlands, the animal and plant residues will not be delayed for a short period. The high amount of water contained in that ecosystem limits the oxygen intensity. Peatlands can be used for agricultural and plantation lands. On the other hand, the unwise uses of peatlands are the common cause of the ecosystems' degradation (Suwatno, 2012).

\subsection{Peatland Characteristics}

Peatlands are unique ecosystems. They are different compared to mineral soils, especially in their physical, chemical, and biological characteristics. From the physical characteristics, peatlands are soft due to the moisture content, brown, sometimes blackish in color. The color of the peat itself can indicate the level of decomposition that has occurred. The faster the decomposition process, the darker the color will be. Another physical characteristic of peatland can be damaged if it experiences drought for a long time. So it is not surprising that during the dry season, many peatlands are no longer able to absorb nutrients and hold water (Masganti et al., 2014).

Based on their chemical properties, peatlands are divided into three structures. The first is eutrophic, which contains high minerals, alkaline compounds, and neutral peat $\mathrm{pH}$ (Masganti et al., 2014). The second arrangement is oligotrophic, mainly filled with low $\mathrm{Ca}$ content and acid reactions. Third, the mesotrophic, which lies between the two structures. Some organic acids are toxic in nature, so that they will harm the plants that live in the land.

\subsection{Peatland Biodiversity}

According to Ariyanto et al. (2005), cited from Wayan (2010), the definition of biodiversity refers to the various types and number of species, genetics, composition, and 
community in an ecosystem or landscape in an area. Peatlands that function as biodiversity conservation are one of the best ecosystems for certain animals and plants. Some types of plants that grow in peatlands are red palms, Nephentes, liran, akar elang, rasau, putat, ara, and others. There are also types of woody plants that can survive in the area, including Bintangur, Kempas, Pulai rawa, Ramin, Meranti rawa, Rengas, and so on. Also, some endemic animals can only be found on Indonesia's peatlands. These animals are storks, jungle sticks, sinyulong crocodiles, proboscis monkeys, linsang with hairy noses, flat-headed cats, and various other types of birds. The types of animals above are now increasingly under threat.

\subsection{Food Security}

Food security has a broad meaning that continues to develop after the holding of the Conference of Food and Agriculture in 1943. However, the concept refers to Food Law Number 7 of 1996 (Suharyanto, 2011). Food security can be defined as the condition of the fulfillment of food needs by all people at any time in a sufficient condition both in terms of quality and quantity to lead a healthy life. If it is related to the situation in Indonesia, food is identical to the raw material for rice. Unfortunately, with the highest growing population of Indonesia and the condition of agricultural land, which is increasingly limited by the day, food needs are increasingly difficult to fulfill.

Also, Indonesia has many types of plants that can be used as a substitute for rice commodities to support national food security, one of which is the breadfruit tree. This plant contains carbohydrates and good nutritional value. Its characteristics can also live on various soils, one of which is in the peatland. The breadfruit tree can produce fruit that can be processed into various forms of healthy food.

\subsection{Conservation}

Based on the Joint Decree of the Minister of Home Affairs, Minister of Forestry and Minister of Public Works (Surat Keputusan Bersama Menteri Dalam Negeri, Menteri Kehutanan dan Menteri Pekerjaan Umum) No.19 / 1984, No.058 / Kpts-II / 84 and No.124 / Kpts / 84, conservation is an effort to maintain or improve land use capacity including soil fertility with the aim of not causing damage and deterioration of land use and productivity. Conservation activities can be realized as long as they are under conservation principles. Some forms of land conservation can be in the form of increasing land use capacity, controlling erosion and flooding, regulating water use, and others. For conservation activities to run well, some steps must be carried out from beginning to end (Wahyudi, 2014).

The conservation start from planning, implementation, technical guidance, maintenance, monitoring, and outreach to the community. So that in its implementation, cooperation with certain parties is required. In this case, the authors collaborate with the local governments and communities. The role of local government is expected to be an intermediary between the author and the community, especially in the socialization of land conservation that will be carried out.

\subsection{Sustainable Development Goals}

Sustainable development is an issue that is being promoted in any country refers to the SDGs that stand for sustainable development goals (Ngoya, 2015). The main problems in the developed fields are social, economic, and environmental. This global action plan has been 
agreed upon by world leaders, one of which is Indonesia intending to reduce poverty, protecting the environment, and reducing existing gaps.

\section{Research Method}

\subsection{Type of Research}

This research is descriptive qualitative research, a form of research conducted to describe various kinds of phenomena as well as the relationships and differences between these phenomena (Sukmadinata, 2006; Linarwati et al., 2016). Qualitative research is a type of research carried out to make an accurate, systematic, and deep description of a phenomenon or object under study. Qualitative research uses an approach that focuses on a deep understanding of an object or phenomenon (Mulyadi, 2013).

\subsection{Methods}

This research was conducted by conducting an in-depth search of various kinds of literature searches related to the research topic. The data collection is carried out systematically until conclusions are obtained that can answer all the questions or problems raised in the research (Sari and Asmendri, 2020).

\subsection{Sampling Technique}

Data used in this study are secondary data obtained from several literature sources related to the research topic. Secondary data are data obtained from other people's writings or publications (Harahap, 2015). In this study, data were obtained from the documentation of several researchers related to peatlands and other related fields. According to Rosa Hutasuhut et al. (2019), data collecting is an activity of tracing various kinds of data related to the topics and themes of the research so that appropriate data are obtained, which will then be analyzed descriptively.

\subsection{Data Analysis}

Data analysis in qualitative research is divided into several stages. The qualitative data analysis stage consists of data collection, data reduction, data presentation, and conclusion (Miles and Huberman, 1992; Rijali, 2019). The first stage is data collection, a stage related to data collection from various data sources. The next step is data reduction. Data reduction is the activity of selecting and transforming data obtained from some data sources. The next stage of data analysis is data presentation. The presentation of qualitative research data can be in the form of narrative text, graphics, networks, or charts. In this study, the author presented the obtained data by presenting some figures that were described descriptively. The last stage is concluding. This stage is carried out after the process of presenting and explaining the processed data carried out (Rijali, 2019).

\section{Result and Discussion}

\subsection{The Design of The Integrated Peatland Management System (IPMS)}


The Integrated Peatland Management System (IPMS) is an integrated peatland management and utilization system. Through the IPMS, it is expected that the potential of peatlands can be used optimally while still paying attention to conservation aspects. IPMS is implemented by adopting the zoning system found in national parks. Through IPMS, the utilization of peatlands does not cause any damage to the land that leads to various other problems, such as the extinction of endemic species. The design of the zoning system in The Integrated Peatland Management System (IPMS) is shown in figure 4.1.

Through IPMS, the peatland will be divided into three zones, including Zone I, Zone II, and Zone III. Each zone has its respective functions. Zone I is the outer zone of peatland that is directly related to community activities. Zone I will be used as an eco-tourism site that is expected to contribute to the surrounding community but still paying attention to environmental sustainability. Zone II is a zone that is directly adjacent to Zone I and located in front of the conservation zone. This zone is used as a productive zone to plant the crop that has the potential to serve as a food source for the surrounding community. Meanwhile, Zone III is the deepest zone of the IPMS peatland zoning system. The zone is used as a conservation zone that aimed to maintain the peatland ecosystem to protect biodiversity, including animals, plants, and microorganisms.

Figure 1. The Design of Integrated Peatland Management System

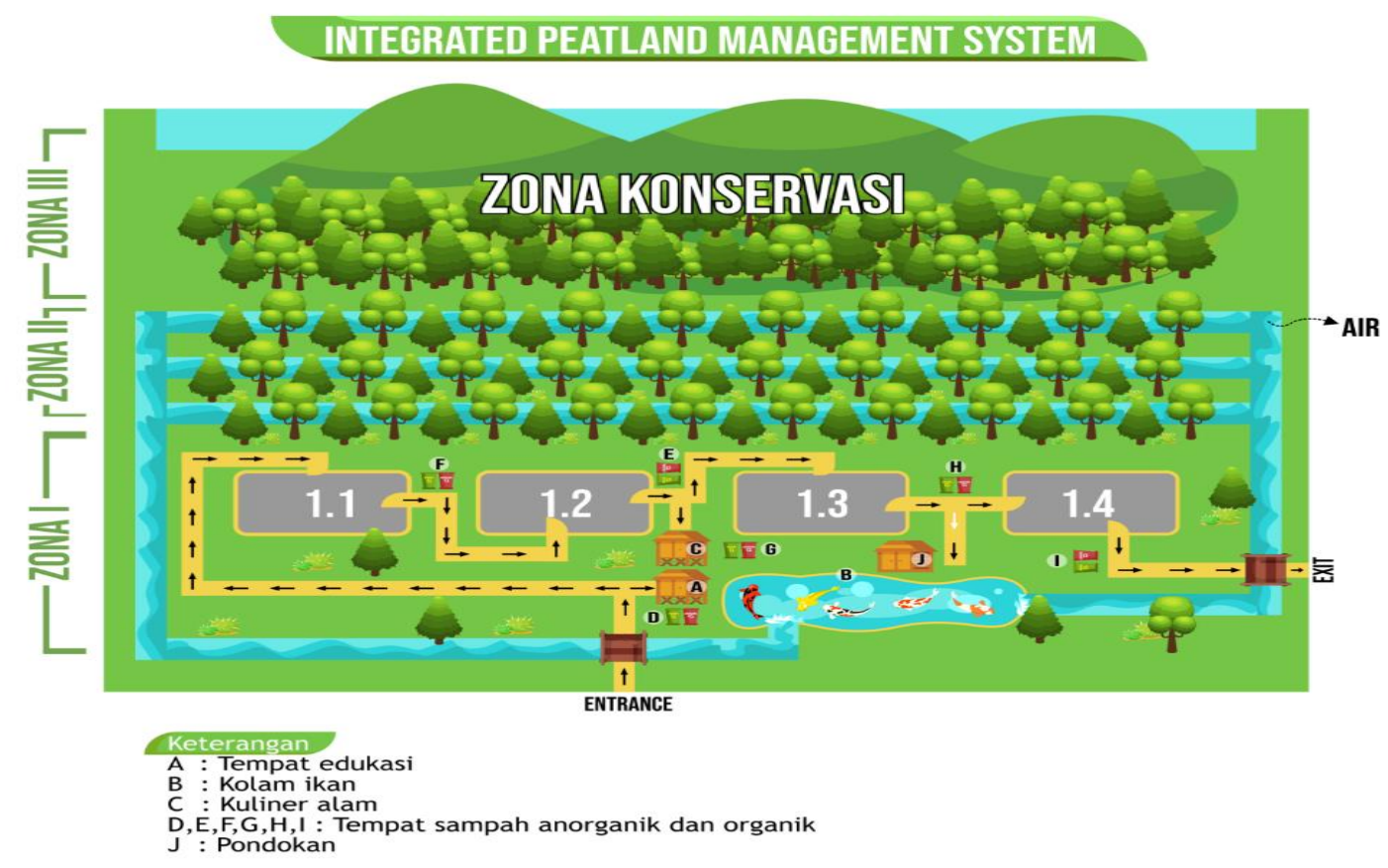

\subsubsection{Zone I (Eco-tourism)}

This first zone of IPMS is used as an eco-tourism site managed by the community. This zone conserves an area of peatland to maximize the economic value of peatland but still maintaining its natural preservation. One of the many vital aspects of peatland conservation is the hydrological cycle of that ecosystem. According to Astiani et al. (2017), the interaction of vegetation, movement of nutrients, and carbon flow are influenced by the hydrological cycle. Their research explained that planting tropical plants as rambutan affects the water flow of the 
ecosystem. As reported by the ASEAN website, Thailand uses peatlands to cultivate some plants as rambutan and wild mango. The tropical plants are suitable to be planted in peatland due to the suitability of environmental factors. The tropical ecosystem is characterized by high annual temperatures and a slight difference between the rainy and dry seasons. However, the effects of global warming make environmental conditions even hotter in the dry season and the floods in rainy seasons due to the problem caused by water absorption ability. Therefore, it is necessary to select tropical plants suitable for the ecosystem.

This zone consists of 4 small zones, including Zone 1.1, Zone 1.2, Zone 1.3, and Zone 1.4. Each zone will be planted with tropical plants that can thrive in peatlands as rambutan, mango, breadfruit, and mangosteen. Zone 1.1 will be developed for rambutan eco-tourism. Rambutan or Nephelium Lappaceum is a plant that contains carbohydrates, vitamin C, calcium $(\mathrm{Ca})$, magnesium $(\mathrm{Mg})$, and potassium $(\mathrm{K})$. This tropical plant grows in various types of soil, with a pH of around 4.5 - 6.5 for optimal growth. Tripathi and Karunakaran (2013) explained that rambutan is very sensitive to level waters and temperatures. The high amount of water contained in the peatland could be overcome by drainages.

Furthermore, Zone 1.2. will be planted by breadfruits (Artocarpus altilis), and Zone 1.3 will be cultivated by mango plants (Mangifera Indica L). These plants are also able to adapt to various types of soil. According to Medina and Garcia (2002), then the best planting distance of each mango plant is $12 \mathrm{~m} \mathrm{x} 12 \mathrm{~m}$. Moreover, Zone 1.4, the exit site of the ecotourism zone, will be cultivated by mangosteen plants (Garcinia Mangostana). Mangosteen is widely found in the humid tropic area of Southeast Asia. Plants with a height of 8-10 m have many benefits in terms of medical and beauty. According to Wulan (2015), mangosteen has tons of health benefits. This plant can protect memory, prevent cell death, and maintain cellular functions. These are caused by the metabolites contained in those plants. Mangosteen contains xanthone, the antioxidant compound that prevents some health disorders.

Not only developed by planting some tropical fruits to attract the tourists, but in the zone, I will also build by developing the Nature School and Education Center. Through the Nature School and Education Centre, the community will be educated about the importance of preserving the peatland ecosystem in supporting human life. The educational center that will be developed in that zone will be integrated into surrounding educational institutions starting from elementary, junior high school, high school to tertiary institutions. Through the education provided at the Nature School, it is expected that the local community, firstly young generations, will realize the importance of preserving the peatland ecosystem so that they can actively be involved in the conservation of the peatland ecosystem. Also, they will know how to utilize the potential of peatlands sustainably.

\subsubsection{Zone II (Utilization)}

Zone II is a zone devoted to peatland use by planting breadfruit. This plant grows in almost all parts of the Indonesian archipelago. According to Muslimah (2018), breadfruit optimally grows with a temperature range of $20^{\circ} \mathrm{C}-40^{\circ} \mathrm{C}$. This plant can grow when it receives a large amount of heat intensity during the dry season. Breadfruit or Artocarpus altilis can grow in any type of soil, whether it is treated or without treatment by a human. However, breadfruit plants should be optimally planted in soil that has organic content with a $\mathrm{pH}$ of 6.0 to 6.5 .

As shown in figure 4.1.2, the cultivation of the breadfruits is made into three parts adjacent to drainage in Zone II, the utilization zone. According to Sudrajat \& Subekti (2019), 
there are two peat areas, the non-cultivation area and the cultivation area. Zone II performs a combination of the two areas. One of the functions of the non-cultivated area is to collect rainwater. The three drainage channels will boil down in the artificial fish pond in Zone I (eco-tourism zone) as water storage during the dry season and as an aquaculture site. Meanwhile, the function of cultivation or utilization area to optimize the sustainable utilization of peatland.

Figure 2. Cultivation Strategy of Breadfruit

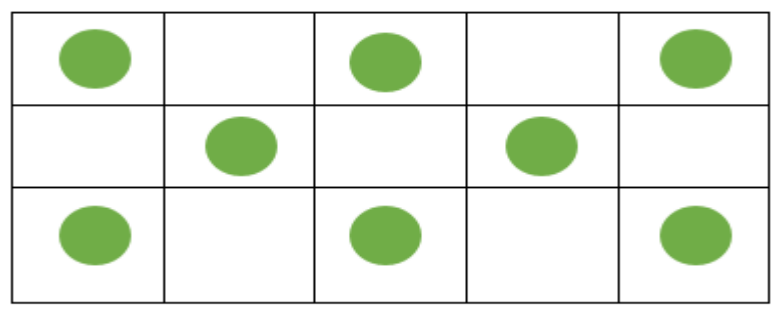

(Source: Nkrumah, 2015)

Cultivating breadfruit next to drainages aims to maintain the hydrological cycle and prevent the peat layer from depleting as well as a barrier between the eco-tourism zone and the conservation zone. According to Dariah et al. (2014), drainages built to increase loadbearing capacity and reduce organic acids contained in peat soil. According to Mausio et al. (2020), breadfruits play a role in maintaining soil stability. The drainage serves the water flow so that that the area around the drainage will become drier and experience land subsidence. To prevent the soil from becoming too dry, breadfruit is planted around the drainage to keep the soil moist. Water in the peat will come out so that it compacts the peat soil and has a loadbearing capacity. By increasing load power, breadfruit will not be collapsed when it has a high weight. Also, drainage reduces organic acids in the soil. Plant growth will be stunted if the soil $\mathrm{pH}$ is too extreme.

To cultivate breadfruit, it is also necessary to pay attention to the arrangement of the saplings. The suitable cultivation arrangement gives adequate light intensity to them. When breadfruit is already mature, it has big leaves, so it is necessary to adjust the distance between the cultivated breadfruit trees. In Figure 4.2, the hexagonal arrangement with a distance between trees of $10 \mathrm{~m}$ aims to increase the plant population. Among the breadfruit trees can be planted with other plant species, especially the local species, to keep the nature of the ecosystem.

Breadfruit will also be cultivated in Zone 1.2. In that sub-ecotourisms zone, there will develop a green culinary center based on breadfruit traditional foods and also some other related foods. This green culinary center will be managed by local communities who are guided in preserving peatlands. Breadfruit can be used as an alternative food source for the local community. It contains carbohydrates used as organic carbon sources for the local community (Sari \& Lestari, 2017). Besides, the green culinary concept also needs to use green cutlery that does not cause any environmental problems in the peat ecosystem. For instance, plates, tablespoons, and cups can be made from coconut shells or banana leaves.

Moreover, according to de Souza et al. (2016), breadfruit contains some mineral compounds, including phosphorus $(\mathrm{P})$, calcium $(\mathrm{Ca})$, magnesium $(\mathrm{Mg})$, Iron $(\mathrm{Fe})$, Sodium, and Manganese (Mn). Phosphorus, calcium, and magnesium are the most abundant minerals in breadfruit. Based on Olaoye \& Ade-Omowaye (2011), breadfruit has properties to reduce 
the potential for heart attacks because it has high fiber that reduces cholesterol and triglycerides.

Moreover, according to de Souza et al. (2016), breadfruit contains some mineral compounds, including phosphorus $(\mathrm{P})$, calcium $(\mathrm{Ca})$, magnesium $(\mathrm{Mg})$, Iron $(\mathrm{Fe})$, Sodium, and Manganese (Mn). Phosphorus, calcium, and magnesium are the most abundant minerals in breadfruit. Based on Olaoye \& Ade-Omowaye (2011), breadfruit has properties to reduce the potential for heart attacks because it has high fiber that reduces cholesterol and triglycerides.

\subsection{Zone III (Conservation Zone)}

Zone III is used as a conservation site for the peatland ecosystem. In this zone, various activities related to the conservation of animals, plants, microorganisms, peat, and all elements that built the peat ecosystem are carried out progressively and actively. All forms of community activities are strictly prohibited from being carried out in this zone. Peatland conservation activities and their constituent parts must actively involve the community either through reforestation activities or monitoring conservation activities. To determine the area of this conservation zone, prior observations must be carried out, as well as data observations regarding the total area of the peatland to be zoned.

There are several activities needed to be carried out in conservating an ecosystem, including peatlands. The first activity is protection. Protection is carried out to protect an ecosystem to avoid various kinds of external influences that lead to many types of damage to the ecosystem. Another activity is to repair the damaged ecosystem (Tobing, 2008).

According to the National Peatland Management Working Group (2006), the area of peatland in Indonesia reaches 20 million hectares. It makes Indonesia one of the countries with the largest peatland in the world. Peatlands have a vital role in the ecosystem. The ecosystem has ecological, economic, and various other functions and values that can support human life (Pramudianto, 2018). Therefore, peatland conservation is needed.

Peatland conservation also vital in carbon absorption and oxygen production, which is an essential substance for living things, including humans (Sudrajat and Subekti, 2019). The plants that are conserved in the land will absorb $\mathrm{CO}_{2}$ from the environment, which will reduce the emission of this pollutant in the environment. Through the process of photosynthesis, plants will also produce oxygen used by various living things in their respiration and metabolisms(Mulyati and Mustika, 2019).

Peatland conservation can be applied through various activities, as by maintaining the natural ecosystem of the peatland and by carrying out reforestation activities. Reforestation is an effort made to restore forest conditions after damage by some factors (Mahyudi et al., 2014). In peatland ecosystems, forest fires are one of the factors destroying the ecosystem (Darmawan et al., 2016). Reforestation can be done naturally or with human assistance. Artificial or human-assisted reforestation is highly needed, especially on damaged peatlands caused by fires that often occur during the dry season (Mahyudi et al., 2014).

Reforestation of destructed peatlands can be done by replanting native plants to restore the natural condition of the ecosystem. The plants found in peatlands include Jelutung wood (Dyera custulata), Ramin (Gonystylus bancanus), Meranti (Shorea spp.), Kempas (Koompassia malaccensis), Punak (Tetramerista glabra), Perepat (Combretocarpus royundatus), Terentang (Campnosperms spp.), Bungur (Lagestroemia spesiosa), Pulai Rawa (Alstonia pneumatophora) and others (Tricahyo et al., 2004; Kelompok Kerja Pengelolaan Lahan Gambut Nasional, 2006). 
Based on the Kelompok Kerja Pengelolaan Lahan Gambut Nasional / National Peatland Management Working Group (2006), peatland conservation needs to involve various institutions and communities. The government is not the only subject of peatland conservation. Community involvement in peatland management is also important. The community must be involved in all peatland conservation activities. Also, peatland management needs to involve various NGOs, especially those engaged in conservation and environmental management. Educational institutions, universities, as well as the private sector also need to be involved in peatland conservation to realize peatland conservation synergically.

Through the Integrated Peatland Management System (IPMS), various kinds of conservation activities will be carried out in Zone III both to protect the peatland ecosystem and to restore the peatland ecosystem. These activities can be applied by formulating some regulations to protect the peatland ecosystem. Peatland protection should involve related parties, such as forest rangers and local communities. The peatland restoration activities are important to restore the natural condition of destroyed peatlands. This activity can be carried out by planting the peatland using native peatland plants.

\section{Conclusions and Recommendations}

\subsection{Conclusions}

a. The Integrated Peatland Management System (IPMS) is an integrated peatland management method that emphasizes conservation aspects. In IPMS, peatlands are divided into three zones, including Zone I (eco-tourism), Zone II (utilization), and Zone III (conservation).

b. Breadfruit can be used as an alternative food source because it contains carbohydrates and minerals needed by the body like Magnesium (Mg), Iron ( $\mathrm{Fe})$, Sodium $(\mathrm{Na})$, Manganese (Mn), Calcium, and Phosphorus.

c. The development of eco-tourism needs to be applied in peatlands by planting tropical plants to attract tourists as well as improve the economic value of the community.

d. Peatland conservation can be done naturally or by human assistance as reforestation of damaged peatlands. Peatland conservation must involve various parties, including the government and related institutions, NGOs, the private sector, and local communities.

\subsection{Recommendations}

Peatland is indeed a fragile ecosystem type. When this ecosystem is managed incorrectly, the function of this ecosystem will be disturbed. Therefore, the parties or stakeholders need to understand the physical and chemical properties before managing peatland. Burning is the wrong way to prepare agricultural land. Burning will contribute to $\mathrm{CO}_{2}$ gas to the earth's atmosphere caused global warming as well as destroyed peatland ecosystems. Therefore, the authors highly recommend applying the IPMS to maximize the natural resources of peatland to support community life. Through IPMS, authors expected that the sustainable utilization of peatlands could be implemented effectively. 


\section{BIBLIOGRAPHY}

\section{Book}

Dariah, A., Eni Maftuah, dan Maswar. 2014. "Panduan Pengelolaan Berkelanjutan Lahan Gambut Terdegradasi." Bogor, Oktober.

Kelompok Kerja Pengelolaan Lahan Gambut Nasional. 2006. Strategi dan Rencana Tindak Nasional-Pengelolaan Lahan Gambut Berkelanjutan. Jakarta: Kelompok Kerja Pengelolaan Lahan Gambut Nasional.

Mahyudi, A., I. Al-Zaqie., J. Gunawan., L. Nurhayati \& Sirajudin. 2014. "Reforestasi Berbasis Masyarakat di Hutan Rawa Gambut." Kalimantan Forests and Climate Partnership (KFCP).

Medina, J. D. L. C., H. S. Garcia. 2002. "Mango post-harvest operations." Instituto Tecnologico de Verscruz, Juni 2002.

Nkrumah, L. B. R. 2015. Breadnut and Breadfruit Propagation. Rome: FAO.

Ritung, S., \& Sukarman. 2016. "Kesesuaian Lahan Gambut untuk Pertanian. In Lahan Gambut Indonesia. Jakarta : IAARD Press.

Tripathi, P.C., dan G. Karunakaran. 2013. "Rambutan cultivation.” Principal Scientist (Hort.) $\&$ Head.

\section{Journal}

Ariyanto, J., Widoretno, S., Agustina, P., Biologi, P., \& Negeri, U. 2005. "Studi Biodiversitas Tanaman Pohon DI 3 Resort Polisi Hutan (RPH) Di Bawah Kesatuan Pemangku Hutan (KPH) Telawa Menggunakan Metode Point Center Quarter (PQC)." Biologi Lingkungan: 502-512.

Astiani, D., Mujiman, and Lisa M Curran. 2017. "Trees of tropical peatland forest influence on variability of water and carbon input through streamflow," Jurnal Biodiversitas 18:383-388.

Darmawan, B., Y.I. Siregar., Sukendi \& S. Zahrah. 2016. "Pengelolaan Keberlanjutan Ekosistem Hutan Rawa Gambut terhadap Kebakaran Hutan dan Lahan di Semenanjung Kampar, Sumatera." Jurnal Manusia dan Lingkungan 23(2):195-205.

De Souza, C. T., Sara A. R. Soares, Antonio F. S. Queiroz, Ana M. P. Dos Santos, Sergio L. C. Ferreira. 2016. "Determination and evaluation of the mineral composition of breadfruit (Artocarpus altilis) using multivariate analysis technique." Microchemical Journal 84-88.

Harahap, N. 2015. "Penelitian Kepustakaan." Jurnal Iqra' 08(01):68-73.

Hutasuhut, A. R. 2019. "Studi Literatur Meningkatkan Kemampuan Berpikir Kreatif Dengan Pendekatan PMR Matematis Siswa." Journal of Mathematics Teacher Education 1(Desember):1-9.

Linarwati, M., A. Fathoni \& M. M. Minarsih. 2016. "Studi Deskriptif Pelatihan Dan Pengembangan Sumberdaya Manusia Serta Penggunaan Metode Behavioral Event Interview Dalam Merekrut Karyawan Baru Di Bank Mega Cabang Kudus." Journal of Management, 2(2):1-8.

Masganti, Wahyunto, Ai Dariah, Nurhayati, R. Y. 2014. "Characteristics and Potential Utilization of Degraded Peatlands in Riau Province." Jurnal Sumberdaya Lahan 8(1):5966. 
Mausio, K., Tomoaki Miura, Noa K. Lincoln. 2020. "Cultivation potential projections of breadfruit (Artocarpus altilis) under climate change scenarios using an empirically validated suitability model calibrated in Hawai'i." Journal PLoS ONE 15(5). Diakses pada 14 Oktober 2020. doi.org/10.1371/journal.pone.0228552.

Mulyadi, M. 2013. "Penelitian Kuantitatif Dan Kualitatif Serta Pemikiran Dasar Menggabungkannya." Jurnal Studi Komunikasi Dan Media 15(1):128. Diakses pada 12 Oktober 2020. https://doi.org/10.31445/jskm.2011.150106

Mulyati, M. \& S. W. A. Mustika. 2019. "Kajian Kebutuhan Oksigen terhadap Ruang Terbuka Hijau Kampus Bangau Universitas Katolik Musi Charitas Palembang." Jurnal Sebatik 23(2): 408-413.

Muslimah, Y. 2018. "The effect of Gandasil D concentration and planting media on root cutting growth of breadfruit." Journal of Agriculture and Veterinary Science 11:52-60.

Ngoya, M. F. 2015. "Mengawal Sustainable Development Goals (SDGs); Meluruskan Orientasi Pembangunan yang Berkeadilan." Sosioreligius I(1):77-88.

Olaoye, O. A., B. I. O Ade-Omowaye. 2011. "Composite Flours and Breads: potential of local crops in developing countries." Academic Press 183-192.

Pramudianto, A. 2018. "Flora dan Fauna pada Ekosistem Lahan Gambut dan Status Perlindungannya dalam Hukum Nasional dan Internasional." Jurnal Pengelolaan Lingkungan Berkelanjutan 2(3):185-199.

Rijali, A. 2019. "Analisis Data Kualitatif." Alhadharah: Jurnal Ilmu Dakwah 17(33):81. Acessed on 9 October 2020. https://doi.org/10.18592/alhadharah.v17i33.2374.

Sari, D. K., dan R. S. D. Lestari. 2017. "The production of breadfruit flour: effect of heater temperature to the drying rate and time of the breadfruit." Jurnal Bahan Alam terbarukan 6(1):20-24.

Sudrajat, A. S. E., \& Subekti, S. 2019. "Pengelolaan Ekosistem Gambut Sebagai Upaya Mitigasi Perubahan Iklim Di Provinsi Kalimantan Selatan." Jurnal Planologi 16(2): 219. Acessed on 9 Oktober 2020. https://doi.org/10.30659/jpsa.v16i2.4459.

Suharyanto, H. 2011. "Ketahanan Pangan." Jurnal Sosial Humaniora 4(2):186-194. Acessed on 11 October 2020. https://doi.org/10.12962/j24433527.v4i2.633

Tobing, I. S. L. 2008. "Manajemen Kawasan dalam Upaya Konservasi Sumberdaya Alam Hayati." Vis Vitalis 1(2):63-70.

Wahyudi, D. 2014. "Teknik Konservasi Tanah serta Implementasinya pada Lahan Terdegradasi dalam Kawasan Hutan." Jurnal Sains \&Teknologi Lingkungan 6(2):71-85. Acessed on 14 October 2020. https://doi.org/10.20885/jstl.vol6.iss2.art1

Wulan, A. J. 2015. "Buah manggis (Garcinia mangostana L.) sebagai alternatif Pelindung memori." Prosiding Seminar Presentasi Artikel Ilmiah Dies Natalis FK Unila ke 13:5863.

\section{Website}

ASEAN. 2010. "Value of peatlands in Thailand." Acessed on 14 October 2020, http://www.aseanpeat.net/index.cfm?\&menuid=145\&parentid=66

Badan Pusat Statistik. 2020.”Jumlah Pengangguran Terbuka 2020." Acessed on 1 October 2020, www.bps.go.id.

SDGs. 2020." Tujuan SDGs." Acessed on 01 October 2020. www.sdgs2030indonesia.org.

Suwatno, A. M. W. 2012. "Eksplorasi Bakteri Penambat Nitrogen dan Bakteri Pelatur Fosfat pada Tanah Gambut di Provinsi Kalimantan Timur'”. Thesis. Universitas Airlangga. 